\title{
Environmental Assessment for Sustainability and Resiliency for Ecological and Human Health
}

\begin{abstract}
Keywords: Assessment; Monitoring; Indicators; Recovery; Resiliency; Ecological health; Human health

\section{Abstract}

Considerable attention has been devoted to environmenta assessment and monitoring, primarily by physical and biologica scientists, and more recently by social scientists. However, population growth and global change have resulted in an imperative to assess the resiliency of the environment to adapt to large scale changes and to continue to produce goods and services for future generations (sustainability). Changing land use needs or expectations may require the remediation and restoration of degraded or contaminated land. This paper provides an overview of monitoring types, and discusses how indicators for the different monitoring types can be developed to address questions of ecological health, human health, and whether restoration and remediation are effective. We suggest that along with more traditional types of monitoring, agencies should consider recovery indicators or metrics, as well as resiliency metrics. We suggest that one goal of assessment should be to determine if management remediation, restoration, and mitigation reduce recovery time, thus reducing community vulnerability and enhancing resiliency to environmental stressors and disasters.
\end{abstract}

\section{Introduction}

There is increasing concern about ecological health and the sustainability of natural ecosystems, especially as they affect human and community health. Scientists, managers, regulators, public policy makers, the public and tribal members are interested in maintaining healthy environments, both for ecosystem protection and for the benefits that they provide. Societies derive goods and services, medicinal products, and religious and cultural benefits from healthy ecosystems. Ecosystems have always faced biological, physical, chemical and radiological stressors, but since the industrial revolution these stressors have increased in magnitude and frequency, as has climate change $[1,2]$. While species assemblages and ecological communities have adapted or adjusted to these stressors, the cumulative effect has ranged from minor to devastation [3-5]. Being able to assess environmental health, and thus human health within an ecological community, is an important societal goal [6-12].

Environmental scientists, ecotoxicologists, and ecologists have developed specific indicators to examine the health of different species, communities, ecosystems, and landscapes [13-18]. At the same time, health professionals and others have developed indicators and biomarkers of human health [8,19]. A range of ecological indicators of ecosystem structure and function (e.g. number of species, population size, number of predators, productivity) was developed for ecosystems $[4,16,20]$, for contaminated ecosystems [11,21-23], for recovering ecosystems [24,25], and for restored ecosystems $[26,27]$. This led to economic evaluation of the goods and services that ecosystems provide [28-30]. Understanding the specific goods and services that ecosystems provide healthy human communities led

\section{Environmental Studies}

\author{
Joanna Burger ${ }^{1-3}$, Michael Gochfeld ${ }^{2,4}$, James \\ Clarke $^{4,5 *}$, Christian Jeitner ${ }^{3}$ and Taryn Pittfield ${ }^{3}$ \\ ${ }^{\prime}$ Division of Life Sciences, Rutgers University, 604 Allison Road, \\ Piscataway, New Jersey, 08854, USA \\ ${ }^{2}$ Environmental and Occupational Health Sciences Institute, Rutgers \\ University, Piscataway, New Jersey 08854, USA \\ ${ }^{3}$ Consortium for Risk Evaluation and Stakeholder Participation, \\ Vanderbilt University (Nashville Tennessee) and Rutgers University, \\ Piscataway, New Jersey, USA \\ ${ }^{4}$ Environmental and Community Medicine, Rutgers-Robert Wood \\ Johnson Medical School, Piscataway, New Jersey, 08854, USA \\ ${ }^{5}$ Civil and Environmental Engineering, Vanderbilt University, \\ Nashville, TN, USA \\ *Address for Correspondence \\ James Clarke, Civil and Environmental Engineering, Vanderbilt \\ University, VU Station B 351831, 2301 Vanderbilt Place, Nashville, \\ TN, 37235, USA, Tel: (615) 322 3897; Fax: (615) 322 3365; E-mail: \\ james.h.clarke@vanderbilt.edu
}

Copyright: () 2015 Burger J, et al. This is an open access article distributed under the Creative Commons Attribution License, which permits unrestricted use, distribution, and reproduction in any medium, provided the original work is properly cited.

Submission: 29 April 2015

Accepted: 15 June 2015

Published: 24 June 2015

Reviewed \& Approved by: Dr. Mark Meo, Professor, Department of Geography \& Environmental Sustainability, University of Oklahoma, USA

to interest in developing indicators of specific goods and services by governmental agencies, Tribal Nations, scientists, conservationists, managers, regulators, and the public [29-32]. Stakeholders should be involved in indicator selection [33], and indicators could be used to monitor global changes [34].

Sustainability can be defined as maintaining ecosystems so that they can continue to provide the goods and services people require for generations to come. Sustainability usually implies ensuring that ecosystems continue to provide these goods and services, but the sustainability and cultural well-being of vulnerable populations is not always considered in environmental assessment. Sustaining biodiversity is widely recognized as desirable, yet preservation of diverse cultures and communities is an important societal value as well. We have previously proposed that indicators can be selected to provide information about ecological health, human health, and the health of diverse cultures (societal/cultural health) $[18,35,36]$. For example, preserving fish stocks to maintain healthy populations and to ensure continued fisheries is an important societal goal, but preserving fish populations because they also have an important cultural and societal value independent of fisheries is not always considered in indicator selection, particularly for Tribal Nations [37,38]. Scientists often assume that indicators developed for the general population apply to vulnerable populations [39] much the same as some people still assume that indicators of human health are automatically protective of eco-receptors. Protecting humans does not necessarily protect eco-receptors because some species are more sensitive to chemicals or other stressors than are humans [40,41].

Recently severe environmental disasters, such as Hurricane 
Katrina along the Gulf coast [42], Superstorm Sandy in the Northeast [43], tornados in the Midwest [44], and long droughts in the west [45] have illustrated the need to develop emergency and disaster planning, recovery, and ways to increase the resiliency of human communities. This paper proposes that environmental managers need to add not only sustainability monitoring to their assessments, but resiliency measures are needed as well. We consider the features that are important for assessment of healthy ecosystems, ecosystem disruptions (natural and anthropogenic), recovery and resiliency, and the effect of ecosystem disruptions on human health. This paper relies on our previous work with monitoring and bio indicators $[10,11,18,36,37,46,47]$ salmon $[18,36,48]$, and stakeholders $[33,39,49,50]$. It involves a synthesis, amplification, and further development of the types of monitoring that are necessary to address ecological, human, and cultural health and well-being. We illustrate some of these concepts using salmon as a case study [18]. Whole books have been written about ecology [5154], as well as each of these topics, the intent of this paper is to provide an overview of the need for resiliency assessment as well as traditional assessment protocols, ecological systems, and a basic paradigm for assessment and biomonitoring to assure sustainability and resiliency.

As used in this paper "resilience" is the ability to prepare and plan for, absorb, recover from, and more successfully adapt to adverse events [55]. Our emphasis on resiliency embodies the following components [56]: 1) ability to mobilize resources for immediate recovery of critical infrastructure, 2) establishment of responsibility for critical decision making before, during, and after events, 3) ongoing assessment of physical, economic, and social vulnerabilities, 4) maintaining a research and evaluation framework for preparedness and recovery.

\section{Background}

Some human communities are changing rapidly, due partly to environmental disasters, such as floods, hurricanes, droughts, partly to economic factors (jobs), and partly to demographic shifts (migration and immigration) [1,43,57-59]. Communities have begun to acknowledge that managing their communities to reduce vulnerability to such storms was an important goal $[60,61]$, and that ecological integrity was part of resiliency $[62,63]$. The need for resiliency assessment and planning applies to nearly every region of the World, including interior areas vulnerable to drought, floods, and tornadoes, particularly given changes in climate [64]. But the need for sustainability assessment and resiliency assessment, within a human/ ecosystem approach, is especially critical for coastal communities. For example, many coastal areas are experiencing rather rapid change as people move toward the coast. Land less than $10 \mathrm{~m}$ above sea level covers $2 \%$ of the World's land, but contains $10 \%$ of the World's population [65], and over half of the US population lives along coasts $[66,67]$. Storms and hurricanes are predicted to increase in frequency and amplitude [5,64,68-71]. Degradation of natural environments is greater in the World's largest cities, even in developing countries [72] The interconnections between the dynamic nature of coastal beaches, dunes, and salt marshes, and adjacent health of human communities have not been recognized by the public, managers, and planners, especially in New Jersey $[63,73,74]$. Shore development for residential and recreational purposes, alters the structure of the beaches. Yet, beaches, and associated dunes and marshes are the first line of defense against severe storms surges and surge tides [75].
Although resiliency is recognized mainly in the aftermath of events, investing in enhancing resiliency is cost-effective in the long run [55]. Disruption of ecological functioning can lead to deterioration of water and air quality, which leads to human health problems, economic instability, and social inequities [76]. Injuries due to storms can be high because of an increase in vulnerability and exposure to coastal flooding [60]. Disasters, such as severe storms, destroy property, threaten human health and the lives of people, strain emergency services and infrastructure, disrupt safety and community operations, and change the structure of coastal ecosystems [57,77-79]. While communication, early warning, and emergency preparedness can help protect communities from the immediate effects of severe coastal storms, long-term resiliency partly depends upon natural and stable ecosystems that serve as a buffer to severe environmental events [80]. The adaptability of human communities to disasters depends not only upon recovery, but on increasing and maintaining resiliency [81]. Understanding the relationship between drivers, pressures, perceptions, impacts and responses is critical to adapting to changing climate and other global changes $[65,76,81,82]$. Developing indicators of resiliency and recovery will be both timeconsuming and costly, but only with such indicators can the efficacy of management be determined.

Personal decisions in the long run about where to live, and, in the short run, about whether or not to evacuate result from the interaction of experience, perceptions of risk, cultural values, reliability of information, and a capacity to act [83]. Therefore, understanding perceptions and valuation of the role of human activities, as well as ecological services are important for future preparedness. Inclusion of stakeholders in decision-making is important to achieve management goals and sustainability [84-87], and to assure "buy-in" for the results of decisions. However, reducing community vulnerability to disasters, and protection of ecological resources, depends upon recognizing the importance of resiliency of both ecological and human communities.

\section{Results}

Although ecosystems are rarely completely stable over long periods of time, there are homeostatic functions that allow health ecosystems to adapt slowly to climatic and demographic changes. Understanding the physical and biological integrity of ecosystems, and the relationship between health of the ecosystems and perturbations provides an integration of the whole such that both ecosystems and human communities have their needs met without compromising the future needs of either one. Further, unique communities, cultures and values need special protection [39,86,88-90]. There are many books and papers on traditional environmental assessment types $[17,24]$ and fewer on ecological assessment $[6,89]$. The challenge for the present and future is to develop; innovative, integrative, multidisciplinary assessment tools that can be used to document, illustrate and communicate progress (or lack of progress) in protecting and restoring environments for the benefit of human quality of life and the integrity of natural ecosystems. This is well-illustrated by the challenges of linking future landuses to post-remediation residual contamination at hazardous waste sites [91], and of enhancing the resiliency of natural and built ecosystems, in the face of the recent increase in frequency and intensity of natural and man-made disasters that are affecting larger and larger areas. 
Citation: Burger J, Gochfeld M, Clarke J, Jeitner C, Pittfield T. Environmental Assessment for Sustainability and Resiliency for Ecological and Human Health. J Environ Stud. 2015;1(1): 8.

ISSN: $2471-4879$

There are several categories of environmental assessment that are essential to evaluate the health and well-being of ecosystems, to manage these systems, and to develop viable, cost-effective and equitable public policies to sustain them. Traditional, ingle disciple approaches have been developed by physical, geological, meteorological, and biological and public health sciences, nontraditional approaches have added political, sociological, economic and regulatory aspects, and innovative, interdisciplinary approaches have included aspects of environmental justice, sustainability, global change, and resiliency. Sustainability is management of opportunities and resources for future generations, and the ability of ecosystems to continue to provide goods and services for societies [92]. All of these assessments can be used individually, or in combination, depending upon both the objectives and the stressors involved.

The field of environmental assessment has grown and changed over the last several decades from traditional, one discipline approaches (e.g. physical, biological, or public health assessments), through non-traditional assessment paradigms (e.g. political, sociological, economic), to innovative multi-disciplinary and interdisciplinary (sustainability, global change, resiliency). The latter is a rather new one that we suggest should be given serious consideration by environmental assessment scientists because it incorporates the principles of physical and biological science with the sociological, economic, political, and cultural needs of communities [93]. Indeed, to truly conduct sustainability or resiliency assessments, all the other types listed in Table 1 are needed; they are components of a more complete assessment.

Given that there is a range of different types of monitoring (with associated indicators), it is important to understand how the different levels of monitoring can be used for different purposes. Table 1 provides examples of types of indicators or biomarkers that can be used for each type of assessment, depending upon whether it is an ecological health assessment, a human health assessment, or one aimed at understanding the efficacy of remediation or restoration. Under most circumstances, agencies or the public have identified a particular assessment need, and can then choose from the available types of assessment, and the question being addressed. This table also illustrates that the same monitoring types can be used for assessing both human and ecological health, and that it can be used to assess management actions. Moving ahead with success we are proposing that there are different types of assessments, some more traditional than others, some physical or biological, some that cross-cut the biological and physical, and some that reflect recovery and resiliency (Figure 1). Human health is subsumed under ecological health, as humans are one eco-receptor among many. We acknowledge, however, that people are more interested in human health generally, than in other eco-receptors. Although Figure 1 is drawn in two dimensions, we can imagine a physical sphere, in which the biological plane fits horizontally, while socio-economic and cultural planes cross cut the sphere. As the sphere changes over in time, recovery from disruptions, resiliency, and sustainability are long-term goals. That is managers and public policy makers who will want to consider these long term goals when managing biological, physical, or social systems. Any one, or a combination of the monitoring levels, can be used to assess sustainability of the system, either undisturbed or following disruptions. Disruptions can involve management or cleanup of contaminated sites, can be negative (a severe storms), or can be positive (restoration). It is the task of environmental managers, governmental agencies, and the public to determine how to apply adaptive management, whereby new protocols rely on past performance and outcomes [94-96]. With the potential for both rapid changes and severe effects from environmental events, it is even more important to adopt adaptive management practices to ensure flexibility in the system.

\section{Salmon: Example of Multiple Monitoring Goals}

We suggest that not all environmental assessment questions

Table 1: Types of Environmental Monitoring with examples for different objectives (types adapted from references $18,37,59$. In some cases the indicators are the same, in others they differ. NA = not applicable for ecosystems.

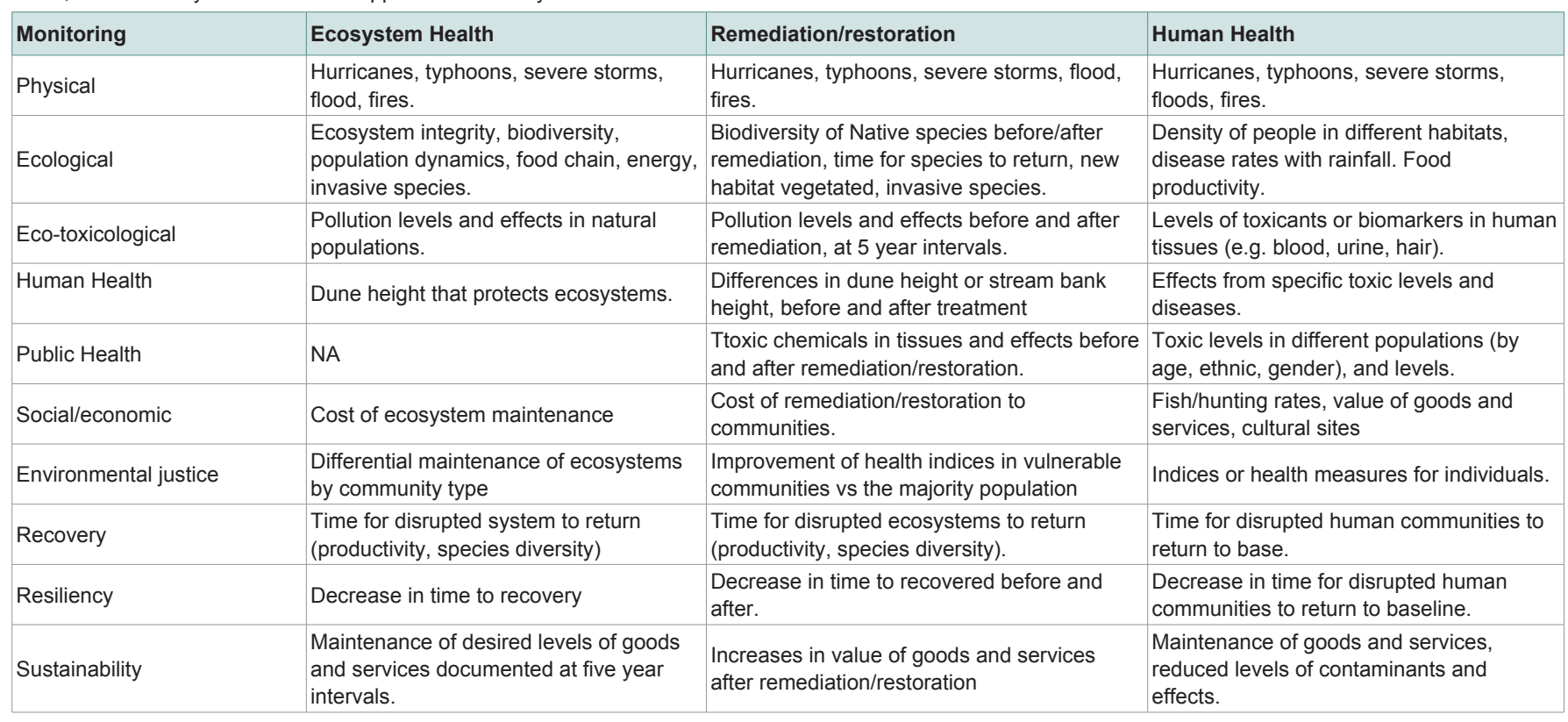


Citation: Burger J, Gochfeld M, Clarke J, Jeitner C, Pittfield T. Environmental Assessment for Sustainability and Resiliency for Ecological and Human Health. J Environ Stud. 2015;1(1): 8.

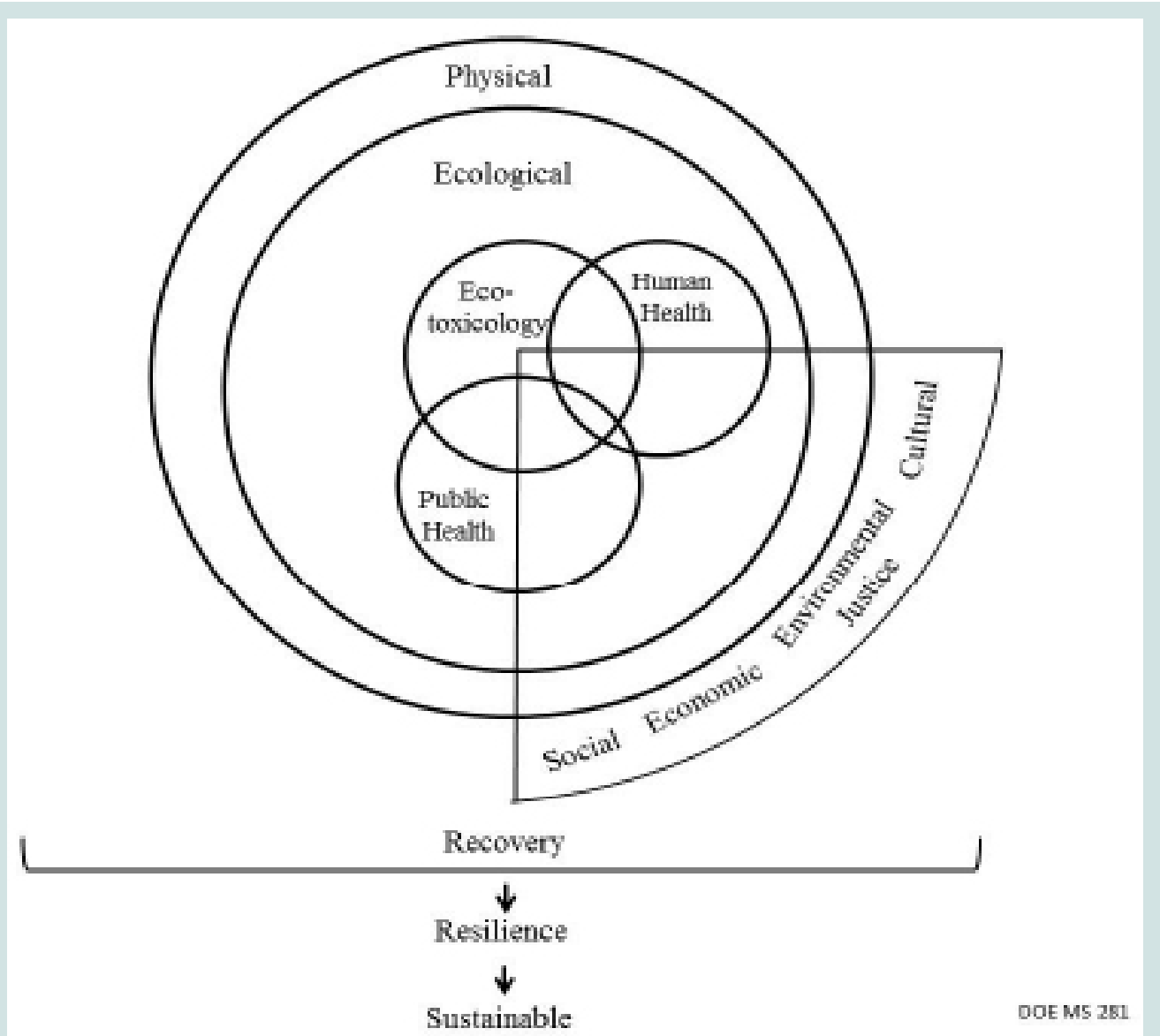

Figure 1: Schematic of the relationship between different types of monitoring. Human and public health fit within ecological monitoring, which itself fits within physical monitoring. All types of monitoring need to take into account social, economic, environmental, and cultural considerations. Monitoring types, and the human dimensions, are essential for understanding and managing recovery, increasing resilience, and ensuring sustainability of systems.

require all of the available monitoring tools. Rather, we suggest that stakeholders, governmental agencies, regulators, and other interested and affected parties select which monitoring tools best address their concerns or problems. We illustrate the applicability of the different types of monitoring using salmon, where the species doesn't matter until the specific objectives are determined.

We use salmon (specifically Chinook salmon Oncorhynchus tshawytscha) as an example to illustrate the kinds of monitoring and indicators that can be used to assess salmon health, ecosystem health, and aspects of human health and well-being (including culture). The endpoints and metrics discussed in Table 2 are meant as examples, and other biologists, public policy makers, tribal members and others will no doubt think of additional metrics, as has the States of Oregon and Washington [??]. Further, different people will value the different monitoring tools and metrics differently. This is a positive thing as it leads to discussions, discourse, and stronger management decisions.

After selecting monitoring type, endpoints need to be selected. In this example, salmon is the indicator. Endpoints relate to one or more aspects of the life cycle or the population dynamics. Salmon have a complex life cycle (Figure 2). Adults' breeds in rivers or streams and lay eggs in nests called "redds". Eggs hatch; fry remain in the nest consuming remaining yolk, then swim up out of the gravel into the water column, and begin to feed. The fish grow into juveniles (called "parr") which migrate downriver, by passing the dams. Eventually the fish reach the ocean where they feed and grow for several years until they reach maturity. The mature adults enter their original or "natal" river system, migrate upriver, through fish "ladders" past dams, until they reach suitable spawning areas. There they build nests, lay and fertilize eggs, and then die $[18,36,52]$. End points or metrics can include: 1) number of adult fish passing upriver through a given fish ladder at a dam, per unit time (day, month, season), 2) number of spawning adult salmon/river mile or per time period, 3) number of nests (redds) per river mile, 4) date of first spawning, 5) viability of the fry, 6) weight or condition of spawning adults. Many of the endpoints (shown with dotted lines) on Figure 2 are ecological, either for individuals or populations, but can also be used to assess ecosystem structure and functioning (e.g. relative to the role of salmon in the ecosystem).

Some of these endpoints can also be used for societal, economic and cultural values. For example: 1) the number of spawning salmon or number of nests/area of river can be used to determine fishing limits for both recreational and commercial harvest, as well as the treaty rights take of Native American Tribes, 2) the average length or weight of salmon can be used to determine condition and size limits for take, and 3 ) the number of salmon visible or counted can 
Citation: Burger J, Gochfeld M, Clarke J, Jeitner C, Pittfield T. Environmental Assessment for Sustainability and Resiliency for Ecological and Human Health. J Environ Stud. 2015;1(1): 8.

ISSN: $2471-4879$

Table 2: Types of Environmental Monitoring for salmon. In some cases the indicators are the same, in others they differ. NA = not applicable for ecosystems Amplification of the data for indicators can be found reference [36], and for some of the metrics currently used by the State of Oregon [??] and Washington [??]. In some cases, the same indicators or endpoints can be used for all four objectives (examples below).

\begin{tabular}{|c|c|c|c|}
\hline Type of Monitoring & Species Health (e.g. salmon) and Ecosystem Health & Remediation/ restoration & Human Health and well-being ${ }^{a}$ \\
\hline Physical & $\begin{array}{l}\text { Dissolved oxygen, water depth, sand pebble size; } \\
\text { percentage of each type; ability to provide sufficient } \\
\text { nesting places }\end{array}$ & $\begin{array}{l}\text { Physical characteristics are better } \\
\text { after than before. }\end{array}$ & $\begin{array}{l}\text { Optimal physical characteristics } \\
\text { better for human goods and services }\end{array}$ \\
\hline Ecological & $\begin{array}{l}\text { Individual and population rates for reproductive success, } \\
\text { predation, competition, productivity; populations sizes } \\
\text { sufficient to sustain salmon role in ecosystem structure } \\
\text { and function }\end{array}$ & $\begin{array}{l}\text { Improvements in rates for } \\
\text { reproductive success, predation, } \\
\text { competition, overall productivity, } \\
\text { populations sizes }\end{array}$ & $\begin{array}{l}\text { Rates of reproductive success, } \\
\text { predation, competition, overall } \\
\text { productivity, populations sizes } \\
\text { sufficient to sustain human cultural } \\
\text { systems }\end{array}$ \\
\hline Eco-toxicological & $\begin{array}{l}\text { Contaminant levels in salmon and organisms that eat } \\
\text { them are high or cause adverse effects }\end{array}$ & $\begin{array}{l}\text { Contaminant levels and effects } \\
\text { lower after than before management } \\
\text { actions }\end{array}$ & $\begin{array}{l}\text { Contaminant levels and effects } \\
\text { low enough to sustain health } \\
\text { ecosystems to provide "safe" goods } \\
\text { and services to communities }\end{array}$ \\
\hline Human Health & $\begin{array}{l}\text { Cases of parasitic or toxic disease from consuming } \\
\text { salmon; Cases of nutritional deficiencies. }\end{array}$ & $\begin{array}{l}\text { Are exposures to people less after } \\
\text { than before action? }\end{array}$ & $\begin{array}{l}\text { Levels sufficiently low in salmon } \\
\text { to ensure food safety, and meet } \\
\text { recreational and commercial needs. }\end{array}$ \\
\hline Public Health & Rates of diseases in population. & $\begin{array}{l}\text { Are exposures of human } \\
\text { populations less after than before } \\
\text { management action? }\end{array}$ & $\begin{array}{l}\text { Are human population sun duly } \\
\text { exposed to contaminants or lack of } \\
\text { cultural values and activities? }\end{array}$ \\
\hline Social and economic & $\begin{array}{l}\text { Money derived from fishing, recreation, commerce } \\
\text { associated with salmon within its ecosystem (e.g. } \\
\text { Columbia River). }\end{array}$ & $\begin{array}{l}\text { Are the economic and social } \\
\text { benefits higher after than before } \\
\text { remediation (using previous } \\
\text { endpoints)? }\end{array}$ & $\begin{array}{l}\text { Are monies and social, economic, } \\
\text { aesthetics derived from salmon } \\
\text { within its ecosystem sufficient? }\end{array}$ \\
\hline Environmental justice & $\begin{array}{l}\text { Individual salmon are healthy and uncontaminated, } \\
\text { numerous }^{\text {b }}\end{array}$ & $\begin{array}{l}\text { Can be demonstrated that the } \\
\text { metrics for healthy salmon } \\
\text { populations are similar in majority } \\
\text { and vulnerable population areas }\end{array}$ & $\begin{array}{l}\text { Population levels and health of } \\
\text { salmon are equivalent in majority } \\
\text { and vulnerable population areas, } \\
\text { including in subsistence regions. }\end{array}$ \\
\hline Recovery & $\begin{array}{l}\text { Length of time for salmon populations to return to a } \\
\text { healthy size, weight, contaminant load, and population } \\
\text { numbers. }\end{array}$ & $\begin{array}{l}\text { Time for salmon populations to } \\
\text { reach a healthy size, weight and } \\
\text { number lower after any disruption } \\
\text { is less following the management } \\
\text { actions }\end{array}$ & $\begin{array}{l}\text { Reduction in the length of time } \\
\text { required for salmon populations } \\
\text { to return to a healthy size, weight, } \\
\text { condition, contaminant loads and } \\
\text { population numbers }\end{array}$ \\
\hline Resiliency & $\begin{array}{l}\text { Reduction in individual and population effects (e.g. } \\
\text { growth rate) due to stressors }\end{array}$ & $\begin{array}{l}\text { Time to reach a healthy state is less } \\
\text { following a range of stressors. }\end{array}$ & $\begin{array}{l}\text { Salmon populations continue to } \\
\text { provide goods and services to } \\
\text { humans. }\end{array}$ \\
\hline Oregon & $\begin{array}{l}\text { Anadromous fish abundance, distribution and life history, } \\
\text { Index of Biotic Integrity, Water quality index, aquatic } \\
\text { habitat }\end{array}$ & $\begin{array}{l}\text { Frequency of meeting in stream } \\
\text { water rights }\end{array}$ & $\begin{array}{l}\text { Changes in land use cover; others } \\
\text { being developed }\end{array}$ \\
\hline Washington & $\begin{array}{l}\text { Indicators for salmon health and watershed health } \\
\text { (Abundance, productivity, habitat conditions). }\end{array}$ & $\begin{array}{l}\text { Funding levels for specific stocks. } \\
\text { Data collection and management } \\
\text { for habitat projects, adopt high level } \\
\text { indicators for recovery }\end{array}$ & $\begin{array}{l}\text { Monitoring of efficacy of measures, } \\
\text { increased accountability of funding } \\
\text {.Include federal, tribal, regional and } \\
\text { local organizations to coordinate } \\
\text { and standardize metrics, }\end{array}$ \\
\hline
\end{tabular}

ancludes cultural and other societal aspects of human well-being.

${ }^{b}$ Vulnerable populations are those of low income, minority, Native American or other underrepresented groups.

be used by Native Tribes to assess whether the salmon stocks have recovered sufficiently to meet their subsistence, cultural, medicinal, and religious needs [97].

The issue of salmon populations, and those of other anadromous fish, has been examined by researchers and the States of Oregon [98] and Washington [99]. In both cases, the primary attention has been focused on the fish themselves (Table 2), while the addition of social and economic indicators is largely agreed upon (e.g. fish takes and salmon allocations, landings, [98]). Both State plans are important because they recognize specific fish stocks and the lack of information that is consistent across species, indicators, and stream systems. The State Plans provide excellent indicators and integration of stakeholders in the process of indicator development to assess salmon and watershed health, while the present paper suggests the need for indigration of the social and economic indicators by the same bodies and documents.

\section{Conclusions and Summary}

We provide an overview of a number of monitoring tools, using salmon as an example and added recovery and resiliency to the 
Citation: Burger J, Gochfeld M, Clarke J, Jeitner C, Pittfield T. Environmental Assessment for Sustainability and Resiliency for Ecological and Human Health. J Environ Stud. 2015;1(1): 8.

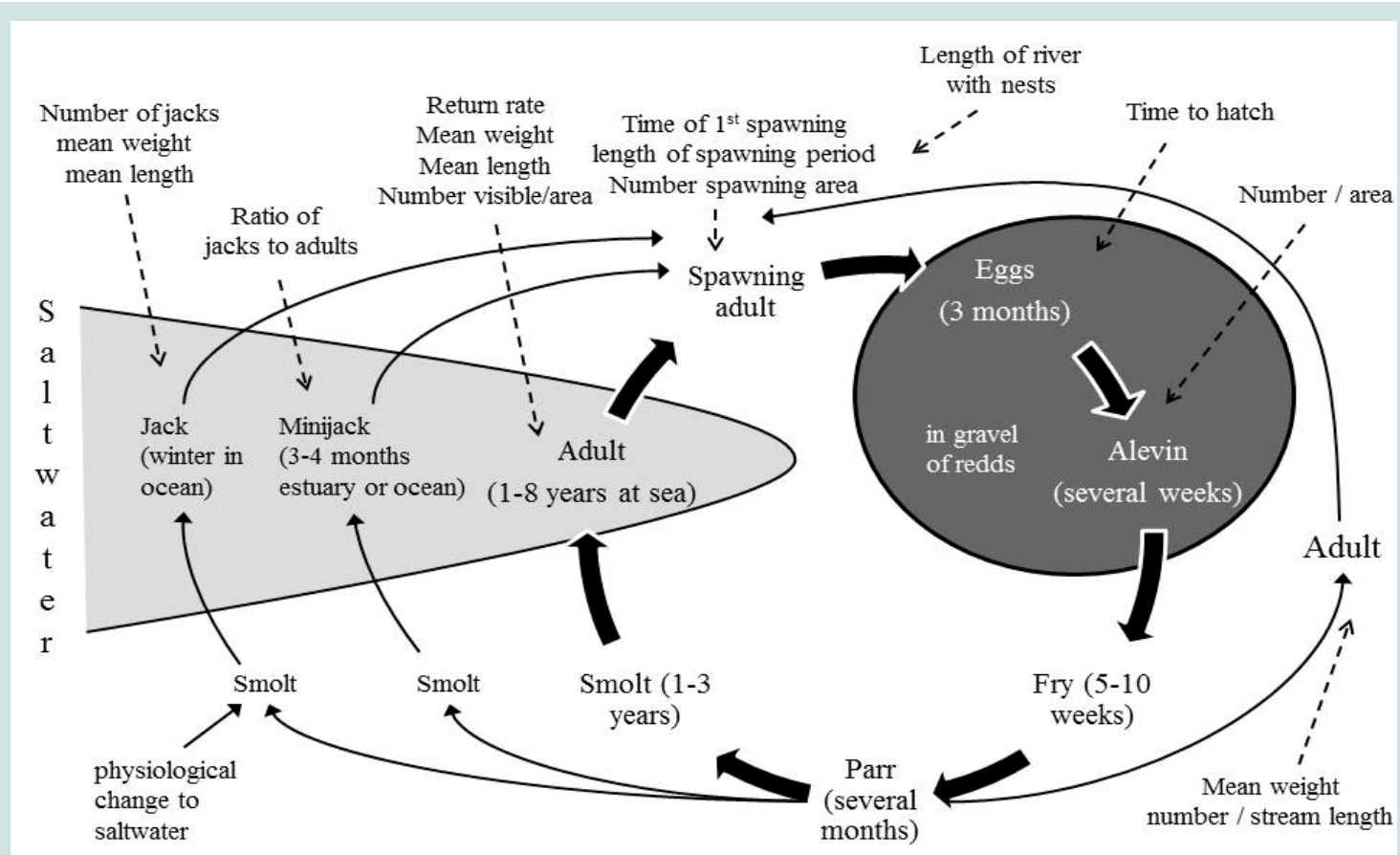

(C) J. Burger

Figure 2: End points that can be selected from the life cycle of salmon. Dotted lines indicate the connection between endpoints and different phases of the life cycle.

monitoring toolbox. We suggest that the monitoring types described not only span traditional monitoring types (e.g. species, populations, abnormalities), but include more recent ones dealing with global change (socio/economic, sustainability). Further, we added recovery and resiliency because with increasing frequency and amplitude of stressors such as severe storms, flooding, and drought (see references in introduction), it is useful to track which measures best describe the ability of ecological and human communities to recover quickly, and be less vulnerable to these stressors (vulnerability). The development of these two monitoring types will take active engagement on the part of the pubic as well as a wide range of scientists, policy makers, resource managers, and regulators [93]. While consensus may not occur quickly, it is none the less essential to begin to dialogue now [100]. By assessing recovery and resiliency with metrics that are clear and definable and can be communicated effectively. Standardized ecotoxicologic paradigms exist, for example, invertebrate and fish toxicity assays [101]. Implementation, evaluation and standardization of more complex assessments will require time and resources. Communities can begin to understand how the ecological and human communities interact to protect one another, and to identify management measures that decrease recovery time, decrease vulnerability, increase resiliency, and increase sustainability of both ecological and human communities and well-being.

\section{References}

1. Lin N, Emanuel KJ, Oppenheimer M, Vanmarcke E (2012) Physically based assessment of hurricane surge threat under climate change. Nat Clim Chang 2: $462-467$.
2. Diffenbaugh NS, Scherer M, Trapp RJ (2013) Robust increases in severe thunderstorm environments in response to greenhouse forcing. Proc Natl Acad Sci U S A 110: 16361-16366.

3. Alexander KS, Ryan A, Measham TG (2012) Managed retreat of coastal communities: understanding responses to projected sea level rise. J Environ Plan Manag 55: 409-433.

4. Doren RF, Trexler JC, Gottlieb AD, Harwell MC (2009) Ecological indicators for system-wide assessment of the greater everglades ecosystem restoration program. Ecol Indic 9: S2-S16.

5. IPCC (2014) Climate change 2014: impacts, adaptation and vulnerability. Intergovernmental panel on climate change. Change, Copenhagen, Denmark.

6. National Research Council (1991) Animals as sentinels of environmental health hazards. Washington, DC. The National Academies Press.

7. Di Guilio RT, Monosson E (1996) Interconnections between human and ecosystem health. Chapman \& Hall.

8. Cole DC, Eyles J, Gibson BL (1998) Indicators of human health in ecosystems: what do we measure? Sci Total Environ 224: 201-213.

9. Fox GA (2001) Wildlife as sentinels of human health effects in the Great Lakes-St. Lawrence basin. Environ Health Perspect 109: 853-861.

10. Burger J, Gochfeld M (2001) On developing bioindicators for human and ecological health. Environ Monit Assess 66: 23-46.

11. Wiersma GB (2004) Bioindicators for assessing human and ecological health. Environmental Monitoring. CRC Press, Flordia, pp: 541-566.

12. Burger J, Gochfeld M (2014) Perceptions of personal and governmental actions to improve responses to disasters such as superstorm sandy. Environ Hazards 13: 200-210.

13. EPA (1997) Ecological indicators: evaluation criteria. Environmental Protection Agency, Washington, DC. 
Citation: Burger J, Gochfeld M, Clarke J, Jeitner C, Pittfield T. Environmental Assessment for Sustainability and Resiliency for Ecological and Human Health. J Environ Stud. 2015;1(1): 8.

ISSN: $2471-4879$

14. EPA (2008) Biological response signatures. Biological indicators of watershed health. Environmental Protection Agency, Washington DC, pp: 1-2.

15. Burger J (2006) Bioindicators: types, development, and use in ecological assessment and research. Environ Bioindicators 1: 22-39.

16. Burger $J(2006)$ Bioindicators: a review of their use in the environmental literature 1970-2005. Environ Bioindicators 1: 136-144.

17. Bartell SM (2006) Biomarkers, bioindicators, and ecological risk assessment-a brief review and evaluation. Environ Bioindicators 1: 60-73.

18. Burger J, Gochfeld M, Powers CW, Clarke JH, Brown K, et al. (2013) Determining environmental impacts for sensitive species: using iconic species as bioindicators for management and policy. J Environ Prot 4: 87-95.

19. Mendelsohn ML, Mohr LC, Peeters JP (1998) Biomarkers: medical and workplace applications. Joseph Henry Press.

20. Carignan V, Villard MA (2001) Selecting indicator species to monitor ecological integrity: a review. Environ Monit Assess 78: 45-61.

21. Fox GA (1994) Bioindicators as a measure of success for virtual elimination of persistence toxic substances: a report based on a workshop held April 28-29, 1992 at the Michigan League, Ann Arbor, Michigan. International Joint Commission, pp: 29-33.

22. Linthurst RA, Bourdeau P, Tardiff RG (1995) Methods to assess the effects of chemicals on ecosystems. Wiley and Sons.

23. Burger J (2007) A model for selecting bioindicators to monitor radionuclide concentrations using Amchitka Island in the aleutians as a case study. Environ Res 105: 316-323.

24. Cairns J (1980) The recovery process in damaged ecosystems. Ann Arbor Science Publishers.

25. Kelly JR, Harwell MA (1990) Indicators of ecosystem recovery. Environ Manag 14: 527-545.

26. Pastorok RA, MacDonald A, Sampson JR, Wilber P, Yozzo DJ, et al. (1997) An ecological decision framework for environmental restoration projects. Ecol Eng 9: 89-107.

27. Ruiz Jaen MC, Aide TM (2005) Restoration success: how is it being measured? Restoration Ecol 13: 569-577.

28. Bingham G, Bishop R, Brody M, Bromley D, Clark E, et al. (1995) Issues in ecosystems valuation: improving information for decision making. Ecol Econ 14: 73-90.

29. Costanza R, d'Arge R, de Groot R, Farber S, Grasso M, et al. (1997) The value of the world's ecosystem services and natural capital. Nature 387: 253260.

30. Costanza R, de Groot R, Sutton P, van der Ploeg S, Anderson SJ, et al (2014) Changes in the global value of ecosystem services. Global Environ Change 26: 152-158.

31. Costanza R (1993) Developing ecological research that is relevant to achieving sustainability. Ecol Appl 3: 579-581.

32. Beratan KK, Kabala SJ, Loveless SM, Martin PJ, Spyke NP (2004) Sustainability indicators as a communicative tool: building bridges in Pennsylvania. Environ Monit Assess 94: 179-191.

33. Burger J (2009) Stakeholder involvement in indicator selection: case studies and levels of participation. Environ Bioindicators 4: 170-190.

34. Risebrough RW (1991) Indicator species, birds, toxic contaminants, and global change. Acta 20: 2480-2486.

35. Burger J, Clarke J, Gochfeld M (2011) Information needs for siting new, and evaluating current, nuclear facilities: ecology, fate, and transport, and human health. Environ Monit Assess 172: 121-134.

36. Burger J, Gochfeld M, Powers CW, Niles L, Zappalorti R, et al. (2013) Habitat protection for sensitive species: balancing species requirements and human constraints using bioindicators as examples. Nat Sci 5: 50-62.

37. Burger J, Gochfeld M, Powers CW, Kosson DS, Halverson J, et al. (2007)
Scientific research, stakeholders, and policy: continuing dialogue during research on radionuclides on Amchitka Island, Alaska. J Environ Manage 85: 232-244.

38. Burger J, Gochfeld M, Jeitner C, Burke S, Stamm T, et al. (2007) Mercury levels and potential risk from subsistence foods from the Aleutians. Sci Total Environ 384: 93-105.

39. Burger J, Gochfeld M (2011) Conceptual environmental justice model for evaluating chemical pathways of exposure in low-income, minority, native American, and other unique exposure populations. Am J Public Health 1: S64-S73.

40. Kopf PG, Walker MK (2009) Overview of developmental heart defects by dioxins, PCBs, and pesticides. J Environ Sci Health C Environ Carcinog Ecotoxicol Rev 27: 276-285.

41. Hengstler JG, Van der Burg B, Steinberg P, Oesch F (1999) Interspecies differences in cancer susceptibility and toxicity. Drug Metab Rev 31: 917-970.

42. Eisenman DP, Cordasco KM, Asch R, Golden JF, Glik D (2007) Disaster planning and risk communication with vulnerable communities: lessons from Hurricane Katrina. Am J Public Health 97: S109-S115.

43. Freedman A (2013) Heeding sandy's lessons, before the next big storm. Climate Central.

44. Greenough G, McGeehin M, Bernard SM, Trtanj J, Riad J, et al. (2001) The potential impacts of climate variability and change on health impacts of extreme weather events in the United States. Environ Health Perspect 109: 191-198.

45. Emberson LD, Kitwiroon N, Beevers S, Büker P, Cinderby S (2012) Scorched earth: how will changes in ozone deposition caused by drought affect human health and ecosystems? Atmos Chem Phys Discuss 12: 27847-27889.

46. Burger J, Gochfeld M, Jewett S (2006) Selecting species for marine assessment of radionuclides around amchitka: planning for diverse goals and interests. Environ Monit Assess 123: 371-391.

47. Burger J, Gochfeld M, Lesser F, Jeitner C, Donio M, et al. (2012) Bioindicators for environmental assessment and monitoring: Metals in wading birds from New Jersey. Int J Environ Sci Eng Res 3: 147-160.

48. Burger J, Gochfeld M, Powers C, Brown K, Clarke J (2015) Using salmon as a bioindicator of the health of the Columbia river at Hanford. Waste Management Symposium. Phoenix, AZ (In press).

49. Burger J (2009) Protecting human health and the environment around nuclear facilities: Native American, stakeholders, and environmental justice. Nuclear Fuels: Manufacturing Processes, Forms, and Safety. Nova Science Publishers, Inc., New York, pp. 165-191.

50. Burger J, Harris S, Harper B, Gochfeld M (2010) Ecological information needs for environmental justice. Risk Anal 30: 893-905.

51. Odum EP (1953) Fundamentals of ecology. Philadelphia, Saunders.

52. Cain ML, Bowman WD, Hacker SD (2008) Ecology. Sinauer Associates.

53. Smith TM, Smith RL (2011) Elements of ecology ( $8^{\text {th }}$ edn). BenjamineCummings Publishing Company.

54. Molles MC (1999) Ecology: Concepts and applications. McGraw-Hill.

55. National Research Council (2012) Disaster resilience: A national imperative. Washington, DC. The National Academies Press.

56. New York State Resiliency Institute for Storms and Emergencies (NYS RISE) (2014) Hurricane Sandy.

57. Neria Y, Shultz JM (2012) Mental health effects of Hurricane sandy: characteristics, potential aftermath, and response. J Am Med Assoc 308: 2571-2572.

58. The Barnegat Bay Beat (2013) Special report: Sandy-A record setting storm. Barnegat Bay Partnership.

59. KratovilC (2012) Drinking water problems cause evacuation of every dorm in New Brunswick. New Brunswick Today.

60. Genovese E, Przyluski V (2013) Storm surge disaster risk management: the 
Citation: Burger J, Gochfeld M, Clarke J, Jeitner C, Pittfield T. Environmental Assessment for Sustainability and Resiliency for Ecological and Human Health. J Environ Stud. 2015;1(1): 8.

ISSN: $2471-4879$

xynthia case study in France. J Risk Res 16: 825-841.

61. Burger J, Gochfeld M (2014) Health concerns and perceptions of central and coastal New Jersey residents in the 100 days following superstorm sandy. Sci Total Environ 481: 611-618.

62. Gallup Organization (2013) Environment. Clim Change.

63. Burger J (2015) Ecological concerns following Superstorm Sandy: stressor level and recreational activity levels affect perceptions of ecosystem. Urban Ecosyst 18: 553-575.

64. NPCC2 (2013) Climate risk information 2013 observations, climate change projections, and maps. New York City Panel on Climate Change. NY.

65. McGranaham G, Balk D, Anderson B (2007) The rising tide: assessing the risks of climate change and human settlements in low elevation coastal zones. Environ Urban 19: 17-37.

66. NOAA (2012) Communities: the U.S. population living at the coast. National Oceanographic and Atmospheric Administration.

67. Crosset K, Cultiton T, Wiley P, Goodspeed T (2013) Population trends along the coastal United States 1980-2008. Coastal Trends Report Series.

68. IPCC (2007) Climate change 2007: synthesis report. Contribution of working groups I, II and III to the fourth assessment report of the intergovernmental panel on climate change. Intergovernmental Panel on Climate Change, Geneva, Switzerland, pp 104.

69. Kharin VV, Zwiers FW, Zhang X, Hegerl GC (2007) Changes in temperature and precipitation extremes in the IPCC ensemble of global coupled model simulations. J Clim 20: 1419-1444.

70. Russo S, Sterl A (2012) Climate and dynamics: global changes in seasonal means and extremes of precipitation from daily climate model data. J Geophys Res 117: 1-11.

71. Lane LK, Charles-Guzman K, Wheeler Z, Abid N, Graber N, et al. (2013) Health effects of coastal storms and flooding in urban areas: A review and vulnerability assessment. J Environ Public Health 2013: 1-13.

72. Burak S, Dogan E, Gazioglu C (2004) Impact of urbanization and tourism on coastal environment. Ocean Coast Manag 47: 515-527.

73. Nordstrom KF, Lotstein EL (1989) Perspectives on resource use of dynamic coastal dunes. Geogr Rev 79: 1-12.

74. Nordstrom KF, Mitteager WA (2001) Perceptions of the value of natural and restored beach and dune characteristics by high school students in New Jersey, USA. Ocean Coast Manag 44: 545-559.

75. Stockdon $\mathrm{H}$, Sallenger A (2010) Impacts and predictions of coastal change during Hurricanes. U S Geological Survey Fact Sheet 2010-3012.

76. Newton A, Carruthers TJ, Icely J (2012) The coastal syndromes and hotspots on the coast. Estuar Coast Shelf Sci 96: 39-47.

77. McLaughlin KA, Fairbank JA, Gruber MJ, Jones RT, Osofsky JD, et al. (2010) Trends in serious emotional disturbance among youths exposed to Hurricane Katrina. J Am Acad Child Adolesc Psychiatry 49: 990-1000.

78. Shear MK, McLaughlin KA, Ghesquiere A, Gruber MJ, Sampson NA, et al. (2011) Complicated grief associated with hurricane Katrina. Depress Anxiety 28: 648-657.

79. North CS, Oliver J, Pandya A (2012) Examining a comprehensive model of disaster-related posttraumatic stress disorder in systematically studied survivors of 10 disasters. Am J Public Health 102: 40-48.

80. Plant NG, Stockdon HF, Sallenger AH, Turco MJ, East JW, et al. (2010) Forecasting hurricane impact on coastal topography. EOS 91: 65-72.

81. Klinenberg E (2013) Adaptation. The New Yorker.

82. Gurian S (2014) Two years after Hurricane Sandy, New Jersey's recovery trudges along. NJ.

83. Casagrande DG (1996) A value based policy approach: The case of an urban salt marsh restoration. Coast Manag 24: 327-337.

84. Jentoft S (2000) Commentary: Co-managing the coastal zone: is the task too complex? Ocean Coast Manag 43: 527-535.

85. Faust BB, Smardon RC (2001) Introduction and overview: environmental knowledge, rights, and ethics: co-managing with communities. Environ Sci Policy 4: 147-151.

86. National Research Council (2008) Public participation in environmental assessment and decision-making. Washington DC. The National Academies Press.

87. Marin V, Palmisani, Ivaldi R, Dursi R, Fabiano M (2009) Users' perception analysis for sustainable beach management in Italy. Ocean Coast Manag 52: 268-277.

88. Butler VL, Connor JE (2004) 9000 years of salmon fishing on the Columbia river, North America. Quat Res 62: 1-8.

89. National Research Council (2000) Ecological indicators for the Nation Washington, DC. The National Academies Press.

90. EPA (2009) Columbia river basin: State of the river report for toxics - January 2009. Washington, DC. United States Environmental Protection Agency.

91. Gochfeld M, Burger J, Powers C, Kosson D (2015) Land use planning scenarios for contaminated land: Comparing EPA, State, Federal, and Tribal Approaches. Waste Management Symposium, Phoenix, AZ (In press).

92. Christensen NL, Bartuska AM, Brown JH, Carpenter S, D'Antonio C, et al. (1996) The report of the ecological society of America committee on the scientific basis for ecosystem management. Ecol Appl 6: 665-691.

93. CEQ (2014) State, local, and tribal leaders task force on climate preparedness and resilience. Council on Environmental Quality.

94. Burger J, Jeitner C, Clark K, Niles L (2004) The effect of human activities on migrant shorebirds: successful adaptive management. Environ Conserv 31: 283-288.

95. Burger J, Carlucci SA, Jeitner CW, Niles L (2007) Habitat choice, disturbance, and management of foraging shorebirds and gulls at a migratory stopover. $J$ Coast Res 23: 1159-1166.

96. Lyons JE, Runge MC, Laskowski HP, Kendall WL (2008) Monitoring in the context of structured decision-making and adaptive management. J Wildl Manage 72: 1683-1692

97. Bohnee G, Matthews J, Pinkham J, Smith A, Stanfill J (2011) Nez perce involvement with solving environmental problems: History, perspectives, treaty rights, and obligations. Stakeholders and Scientists, pp: 149-184.

98. Dent L, Salwasser H, Achterman G (2005) Environmental indicators for the oregon plan for salmon and watersheds. Institute for Natural Resources, Oregon State University.

99. Crawford BA (2007) Washington state framework for monitoring salmon populations listed under the federal endangered species act and associated freshwater habitats. The Governor's Forum on Monitoring Salmon Recovery and Watershed Health, Olympia, Washington.

100.Burger J, Gochfeld M, Pletnikoff K (2009) Collaboration versus communication: The department of energy's Amchitka Island and the Aleut community. Environ Res 109: 503-510.

101.EPA (2015) ECOTOX: ecotoxicology database. Environmental Protection Agency, Washington, DC.

\section{Acknowledgements}

We thank the many people who have discussed these topics with us, or who have helped in the research, including C. W. Powers, K. Kosson, K. Brown, L. Bliss, M. Gilbertson. This project was mainly funded by the Consortium for Risk Evaluation with Stakeholder Participation (Department of Energy, DE-FC01-86EW07053), with additional funding from NIEHS (P30ES005022) and Rutgers University. The views and opinions expressed in this paper are those of the authors, and do not represent the funding agencies. 